Article

\title{
Perpendicular intergrowth ZSM-5 plates with shortened 10-MR pores
}

\author{
Ensheng Zhan a, Zhiping Xiong a,c, Yan Zhou a, Mingrun Li a, Pengfei Wang b, Weibin Fan b, \\ Wenjie Shen a,* \\ a State Key Laboratory of Catalysis, Dalian Institute of Chemical Physics, Chinese Academy of Sciences, Dalian 116023, Liaoning, China \\ b State Key Laboratory of Coal Conversion, Institute of Coal Chemistry, Chinese Academy of Sciences, Taiyuan 030001, Shanxi, China \\ c University of Chinese Academy of Sciences, Beijing 100049, China
}

\section{A R T I C L E I N F}

Article history:

Received 11 November 2019

Accepted 24 December 2019

Published 5 July 2020

\section{Keywords:}

ZSM-5

Plate structure

Perpendicular Intergrowth

Channel length

Hierarchical structure

Molecule diffusion

\begin{abstract}
A B S T R A C T
ZSM-5 plates with a perpendicular intergrowth structure was synthesized by using a simple amine as the structure directing agent under hydrothermal conditions, in which the mother plate and the perpendicularly standing plates oriented along the (010) and (100) planes of MFI crystals, respectively. During the crystallization process, the mother plate was initially formed on the surface of the amorphous solid gel, while a set of parallel plates perpendicularly grew on its surface, via a homogeneous nucleation mechanism. The mother plate and the perpendicular plates had a similar thickness of 100-200 nm and were characterized by considerably shortened straight and zigzag 10 member ring pores, respectively. This unique intergrowth structure greatly facilitated the diffusion of the reactive molecules in HZSM-5 crystals during methanol conversion to hydrocarbons.
\end{abstract}

(C) 2020, Dalian Institute of Chemical Physics, Chinese Academy of Sciences. Published by Elsevier B.V. All rights reserved.

\section{Introduction}

Crystalline microporous zeolites are industrially used to catalyze the conversion of hydrocarbons and alcohols. The acid sites mainly located in the pores/cavities that are close to the dynamic sizes of the reactive molecules, showing the prominent shape-selective catalysis behavior [1]. However, the crystal sizes of zeolites, in contrast to the much smaller size of the micropores, are rather large, usually with dimensions of several micrometers. Thus, the accessibility of molecules to the active sites inside the micropores are restricted by the long channel length and the limited number of pore openings on the zeolite crystal surfaces. Moreover, the long diffusion pathway induces re-adsorption and sequential reaction of the intermediates and products inside the micropores, yielding heavy aro- matics and cokes that are commonly referred as to the main reason for catalyst deactivation [2].

Shortening the micropores has been typically adapted to alleviate the diffusion limitations, which would significantly reduce the intra-crystal diffusion length and enhance the accessibility of the active sites. Creating mesopores in zeolite crystals, reducing crystal size and modulating crystal morphology are the most popular strategies [3]. Creation of mesopores in zeolite crystals is typically done by post-treatments of the zeolites via acid- and/or base-leaching to partially remove the framework atoms (dealumination and/or desilication), generating mesopores that intersected with the micropores [4-6]. Decreasing the crystal size to the nanometer scale $(<100 \mathrm{~nm})$ is usually achieved by adding growth inhibitors [7], quenching the crystallization [8] and controlling the nucleation rate $[9,10]$

\footnotetext{
* Corresponding author. Tel: +86-411-84379085; Fax: +86-411-84694447; E-mail: shen98@dicp.ac.cn This work was supported by the National Natural Science Foundation of China (21773229).

DOI: 10.1016/S1872-2067(20)63573-2 | http://www.sciencedirect.com/science/journal/18722067 | Chin. J. Catal., Vol. 41, No. 7, July 2020
} 
during the hydrothermal synthesis. Tuning the morphology of zeolite crystals reduces the size of crystals at a certain dimension to nanometer scale while keeps the other dimensions in micrometer scale. For zeolites with intersecting pore systems, such a strategy is expected to maintain the long-range ordering of the pore structure in the micro-sized dimension while benefit the diffusion of molecules along the nanometer dimension. This is crucially important for shape-selective reactions that occur at the acid sites located in the pores along the micro-sized dimensions [11].

ZSM-5 is among the most important and widely used zeolites in both fundamental studies and industrial applications. Its MFI-type topology is characterized by the straight 10 member ring (10-MR) channels $(5.3 \times 5.6 \AA)$ along the $b$ axis, intersecting with the zigzag 10 -MR channels $(5.1 \times 5.5 \AA)$ along the $a$ axis. Morphology modulation of ZSM-5 to nanosheets and self-pillared architectures has been demonstrated to remarkably reduce the diffusion length in the micropores [12-18]. ZSM-5 nanosheets with a single-unit-cell thickness of $2 \mathrm{~nm}$ was synthesized using a unique gemini-type diquaternary ammonium as the structure-directing agent (SDA) under hydrothermal conditions [12]. This bi-functional SDA has a head group with hydrophilic diquatenary ammonium cations to direct the formation of MFI layers and a hydrophobic tail to prevent the continuous growth along the $b$ axis. The ultrathin nanosheets significantly shortened the straight channels and largely facilitated molecule diffusion, but tended to aggregate upon thermal treatment. This requires an additional pillaring by silica before removing the SDA to maintain the inter-sheet space voids [13]. Self-pillared MFI/MEL nanosheets were synthesized with the aid of tetrabutylphosphonium, in which the perpendicularly intergrowth MFI/MEL nanosheets of $2 \mathrm{~nm}$ thick stacked into a "house of cards" structure, following an epitaxially twin growth mechanism [14]. Self-pillared MFI was also prepared by using specially designed SDAs, such as multi-quaternary ammonium $[15,16]$ and diquaternary ammonium cations with 5 or 6 carbons between the two ammonium cations $[17,18]$. Possibly, the mismatch of the carbon chain length between the ammonium cations with the distance between intersections along the MFI channels resulted in framework distortion due to structural constraints or stresses, which hindered crystal growth along certain directions and induced crystal intergrowth [17].

MFI nanosheets and self-pillared structures provided a strategy for reducing the diffusion length in the micropores. However, they usually suffer from the use of specially designed SDAs which are rather complex in assembly the function groups. Considering the potential applications of these nanostructured zeolites in chemical industries, developing synthetic approach by using commonly available and simple SDAs would be of fundamentally and practically interest. In this work, we synthesized perpendicular intergrowth ZSM-5 plates by using a simple SDA (triethylene diamine, TEDA), in which the mother plate and the perpendicularly standing plates oriented along the (010) and (100) planes of the MFI crystals, respectively. The resulting HZSM-5 catalyst showed high stability in methanol to hydrocarbons, simply because of the greatly facilitated molecule diffusion within the 10-MR pores.

\section{Experimental}

\subsection{Synthesis of ZSM-5 plates}

ZSM-5 plates were synthesized by a hydrothermal method. In a typical procedure, $0.32 \mathrm{~g} \mathrm{NaOH}$ (96\%, Sinopharm Chemical Reagent), 0.656 g sodium aluminate (Sinopharm Chemical Reagent, $28.3 \% \mathrm{Al}$ as determined by ICP), $24 \mathrm{ml}$ distilled water, 20 $\mathrm{g}$ triethylene diamine (Energy Chemicals, Shanghai) and $20 \mathrm{~g}$ Ludox As-40 (40\% $\mathrm{SiO}_{2}$, Sigma Aldrich) were mixed at room temperature and stirred for $3 \mathrm{~h}$. The mixture was then transferred into a Teflon-lined stainless-steel autoclave and hydrothermally treated at $150^{\circ} \mathrm{C}$ for a desired period under dynamic conditions. The solid product was collected by filtration, washed with distilled water, dried at $110{ }^{\circ} \mathrm{C}$ overnight, and calcined at $550{ }^{\circ} \mathrm{C}$ in air for $10 \mathrm{~h}$.

The HZSM- 5 catalyst was obtained by ion-exchange of the as-calcined ZSM-5, which was conducted sequentially for three times with a $1.0 \mathrm{M} \mathrm{NH}_{4} \mathrm{NO}_{3}$ aqueous solution at $80{ }^{\circ} \mathrm{C}$ for $6 \mathrm{~h}$. The solid product was collected by filtration, dried at $110{ }^{\circ} \mathrm{C}$ overnight and calcinated at $540{ }^{\circ} \mathrm{C}$ for $5 \mathrm{~h}$ in air.

\subsection{Characterization}

Elemental analysis was performed using X-ray fluorescence (XRF) spectroscopy with a PANalytical spectrometer.

Powder X-ray diffraction (XRD) patterns were recorded on a D/MAX 2500/PC diffractometer (Rigaku, Japan) using a Cu $K_{\alpha}$ radiation source that was operated at $40 \mathrm{kV}$ and $200 \mathrm{~mA}$.

Nitrogen adsorption-desorption isotherms were recorded on a Micromeritics ASAP2020 adsorption analyzer at $-196{ }^{\circ} \mathrm{C}$. Before the measurement, the sample was outgassed at $300{ }^{\circ} \mathrm{C}$ for $5 \mathrm{~h}$. The micropore surface area and volume were calculated using the $t$-plot method.

Field-emission scanning electron microscopy (FESEM) images were taken on a Philips FEI Quanta 200F microscope operated at $20 \mathrm{kV}$. Transmission electron microscopy (TEM) images were recorded on a FEI Tecnai G2 Spirit microscope at $120 \mathrm{kV}$; scanning transmission electron microscopy (STEM) and high-resolution transmission electron microscopy (HRTEM) images were recorded on a JEOL ARM 200F at 200 $\mathrm{kV}$.

Solid-state magic-angle-spinning (MAS) nuclear magnetic resonance (NMR) experiments were done on a Varian Infinityplus-400 spectrometer. ${ }^{29} \mathrm{Si}$ MAS NMR spectra were obtained at 79.4 MHz using 7.5 m MAS probe with a spinning rate of 10 kHz. The chemical shifts were referenced to DSS (4,4-dimethyl-4-silapentane-1-sulfonic acid). ${ }^{27} \mathrm{Al}$ MAS NMR spectra were recorded at a resonance frequency of $104.2 \mathrm{MHz}$ with a spinning rate of $10 \mathrm{kHz}$, and the chemical shifts were referenced to $\left(\mathrm{NH}_{4}\right) \mathrm{Al}\left(\mathrm{SO}_{4}\right)_{2} \cdot 12 \mathrm{H}_{2} \mathrm{O}$ at $-0.4 \mathrm{ppm}$.

\subsection{Reaction test}

Methanol to gasoline (MTG) reaction was carried out with a continuous flow fixed-bed reactor (i.d. $10 \mathrm{~mm}$ ). $1.5 \mathrm{~g}$ HZSM-5 was pretreated with $\mathrm{N}_{2}(30 \mathrm{~mL} / \mathrm{min})$ at $500{ }^{\circ} \mathrm{C}$ for $2 \mathrm{~h}$ and the 
reaction was then tested at $363{ }^{\circ} \mathrm{C}$ and $0.4 \mathrm{MPa}$. Methanol was pumped into the reactor with a liquid weight-hourly space velocity (WHSV) of $1 \mathrm{~h}^{-1}$. The gas and liquid products were separated via a cold trap and analyzed with gas chromatography according to a previously described procedure [19].

\section{Results and discussion}

Fig. 1 shows the textural characters of the typical ZSM-5 plates obtained at $150{ }^{\circ} \mathrm{C}$ for $120 \mathrm{~h}$ under hydrothermal conditions. The XRD pattern showed characteristic diffraction lines of MFI type zeolite (PDF \# 39-0225), while the $\mathrm{N}_{2}$ adsorption exhibited typical type I isotherm with a sharp uptake at $P / P_{0}<$ 0.02 , indicating the micropores. The micropore volume and surface area were $0.12 \mathrm{~cm}^{3} / \mathrm{g}$ and $251 \mathrm{~m}^{2} / \mathrm{g}$, respectively. The SEM images showed an intergrowth pattern of the sample. The mother plate was of several micrometers $(3-5 \mu \mathrm{m})$ wide and 100-200 nm thick, while a set of mainly parallel plates, $1-2 \mu \mathrm{m}$ wide and 100-200 nm thick, perpendicularly grew on the mother plate. Such an intergrowth manner of ZSM-5 plates essentially differs from the case of repeated branching plates that propagated into 'house of card' morphology [14-18].

Detailed TEM analysis elucidated the intergrowth pattern of the ZSM-5 plates. As shown in Fig. 2, the mother plate had an octagonal shape, which is different from the typically displayed hexagonal shape of MFI crystals on the (010) plane [20-22]; the sharp dots of the SAED patterns, collected from the bare mother plate and the area with intergrowth plates, indicated the single-crystal nature of these areas. The two SAED patterns are essentially the same and could be indexed to the diffraction patterns of MFI along the [010] axis, indicating that the mother plate is orientated with the (010) plane. Thus, the straight 10-MR channels (along the $b$ axis) runs perpendicular to the mother plate. Furthermore, the bright-field and high-angle annular dark-field STEM images of the mother plate evidenced pore openings on the surface. That is, the mother plate is characterized by $100-200 \mathrm{~nm}$ straight channels with abundant pore openings on the large surface.

The perpendicular standing plates are in parallel with each other on the mother plate. The single crystal nature of the intergrowth area confirmed a lattice-matched epitaxial growth of the standing plates. It is worth noting that the standing plates run parallel to the $c$ axis of the mother plate, affirming that they were orientated with the (100) plane of the MFI crystal and thus the zizag 10-MR channels were shortened to 100-200 nm along the $a$ axis. Such an intergrowth mode of MFI crystals with protuberance running parallel to the $c$ axis of the mother crystal was previously observed as well, but only one branch, rather than a set of parallel ones, presented $[20,22,23]$. It is generally acknowledged that the mismatch of the SDAs with the MFI channels induced crystal intergrowth [17], although the detailed mechanism remains unclear. ZSM-5 was experimentally obtained at $\mathrm{SiO}_{2} / \mathrm{Al}_{2} \mathrm{O}_{3}$ ratios of 40 by using TEDA as the structure directing agent, but theoretical calculations verified a better fitting of TEDA with MCM-22 at $\mathrm{SiO}_{2} / \mathrm{Al}_{2} \mathrm{O}_{3}$ ratio of 20-40 [24,25], possibly because ZSM-5 was the common product at $\mathrm{SiO}_{2} / \mathrm{Al}_{2} \mathrm{O}_{3}$ ratio of 40 even in the absence of amine. Anyway, this result suggested that TEDA is not perfectly matched with the MFI channels. Therefore, the perpendicular intergrowth of MFI crystals could be ascribed to the non-perfect match of the SDAs, like diquaternary ammonium cations $[17,23]$, with its pore structure. Here, TEDA may have a
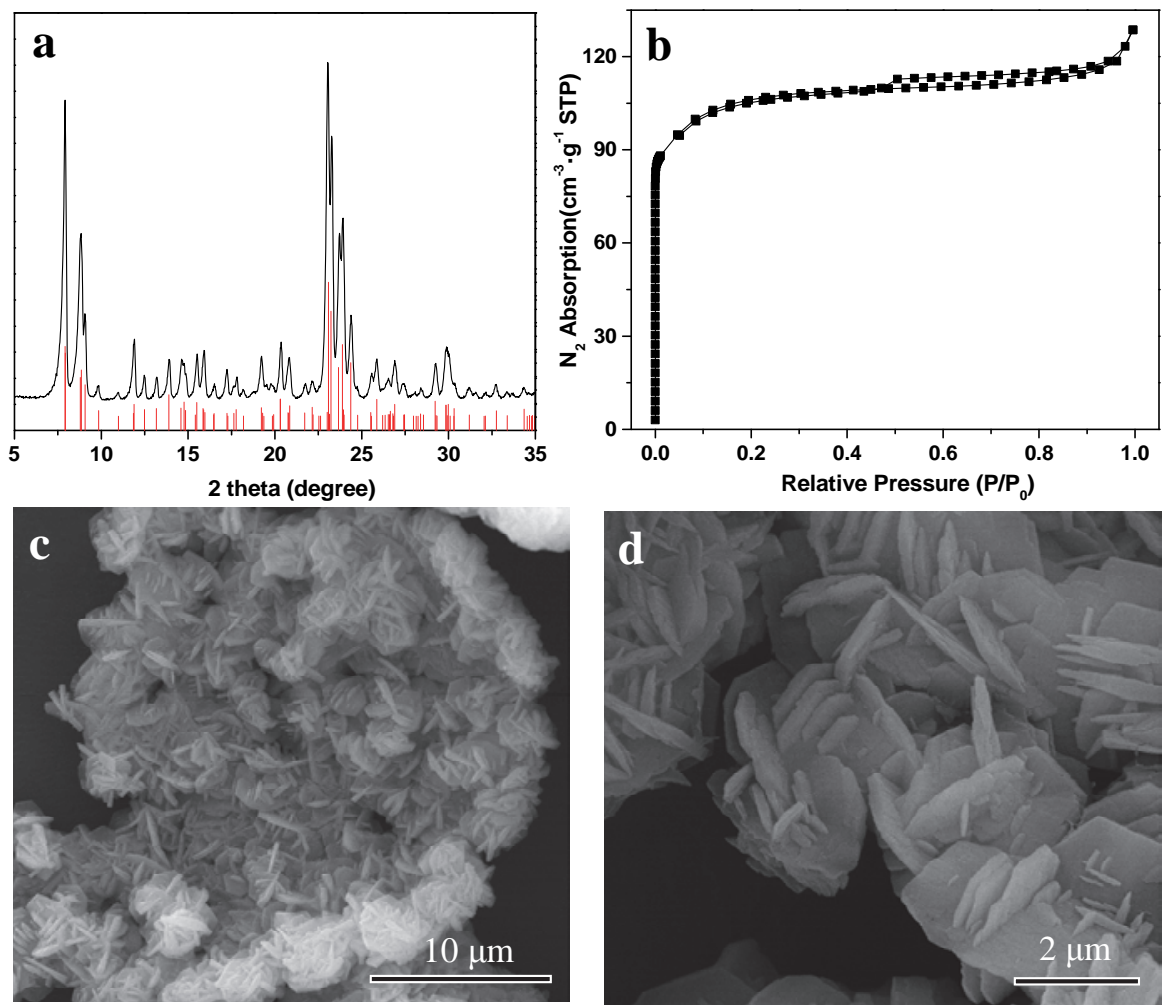

Fig. 1. XRD pattern (a), $\mathrm{N}_{2}$ adsorption-desorption isotherms (b) and SEM images (c,d) of the ZSM-5. 


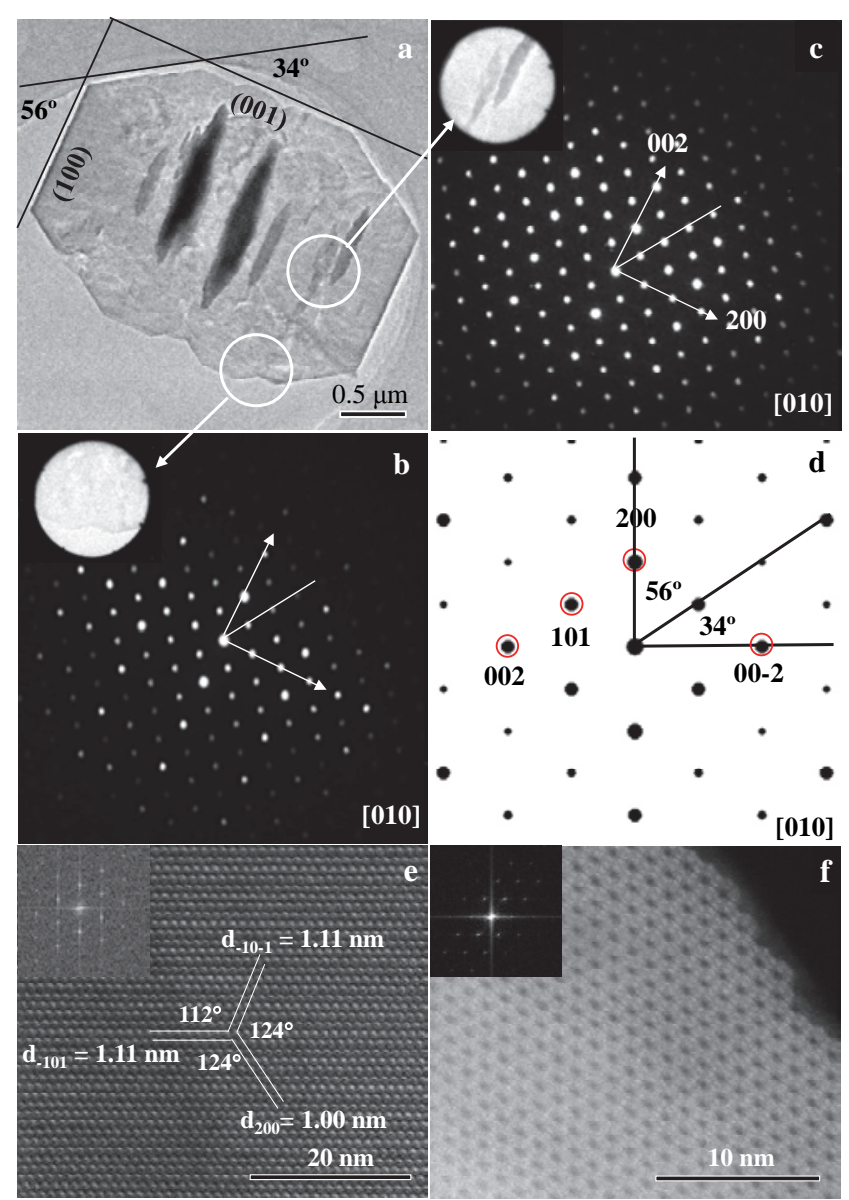

Fig. 2. TEM image (a), SEAD patterns of the bare mother plate (b) and the intergrowth area with standing plates (c), schematic representation of the diffraction patterns of MFI along the [010] direction (d), bright-field (e) and high-angle annular dark-field (f) STEM images of the ZSM-5.

similar effect in directing the intergrowth of the standing plates, but the unusual octagonal shape of the mother plate and the parallel intergrowth pattern of a set of perpendicular standing plates indicated a unique structure directing effect of TEDA on the crystallization process of ZSM-5.

To explore the formation mechanism of the intergrowth plates, the structure evolution of ZSM-5 was examined by analyzing the solid products at different intervals by XRD and SEM. As indicated by the XRD patterns (Fig. 3), only amorphous material was obtained at $48 \mathrm{~h}$, while weak diffractions of MFI appeared after $72 \mathrm{~h}$; the diffraction intensity increased gradually from 72 to $96 \mathrm{~h}$ and well crystallized ZSM-5 was formed at 120 $\mathrm{h}$. The corresponding SEM images confirmed this growing procedure (Fig. 4). Amorphous worm-like aggregates were formed at $48 \mathrm{~h}$ and were still dominant at $72 \mathrm{~h}$; small amount of crystalline plates appeared at this stage, but most plates had no obvious intergrowth pattern. The amount of crystalline plates increased dramatically at $96 \mathrm{~h}$ and some smaller plates started to stand on the mother plate. Crystalline plates with distinct intergrowth structure were clearly seen at $120 \mathrm{~h}$. It seems that the transformation from amorphous particulate to a single plate occurred within a relatively short period, and the plates were formed sequentially by consuming the amorphous parti-

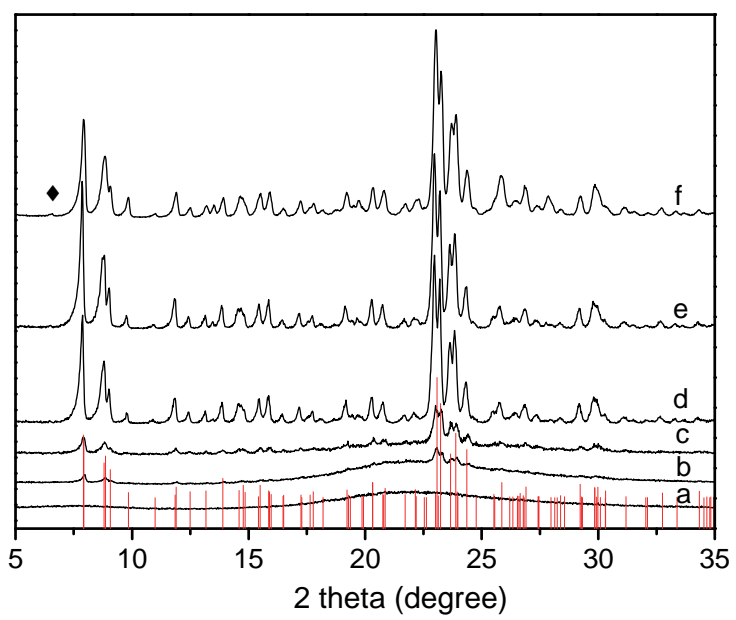

Fig. 3. XRD patterns of the samples after hydrothermal synthesis for 48 h (a), 72 h (b), 96 h (c), 120 h (d), 168 h (e), and 240 h (f).

cles, which lasted for a long period (48-120 h) to reach a full crystallization. A set of small plates perpendicularly grew on the surface of a single plate, once it formed, to construct the intergrowth structure. This crystal growth mode, which takes a relatively longer time span from the initial crystallization to the full crystallization, is similar to that of self-pillared MFI by using 1,5-bis(trimethylamonium)pentyl diquaternary ammonium cation as the SDA [17]. But it is totally different from the classical zeolite crystallization process that is characterized by the autocatalytic crystal nucleation: a full crystallization could be quickly reached once the crystallization is initiated [26-28]. Instead, the SEM images indicate a classical homogeneous nucleation mechanism, in which nucleation of zeolite crystals are originated from the solution phase and occur at the boundary of the amorphous solid gel and the surrounding solution [21]. Again, this excluded the particle attachment mechanism that has been frequently observed in the crystallization of MFI zeolites [29-31].

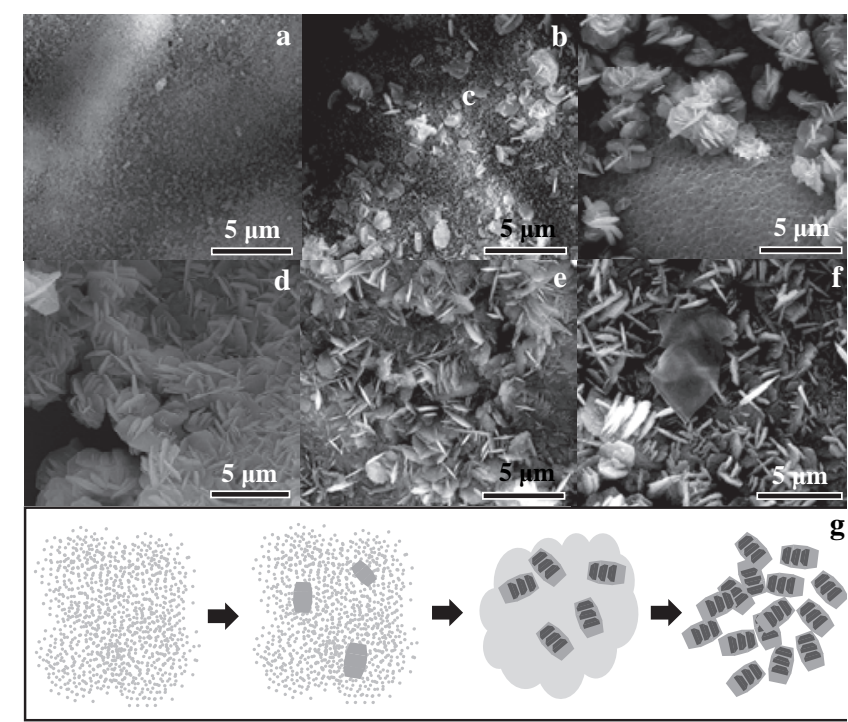

Fig. 4. SEM images of the samples after hydrothermal synthesis for $48 \mathrm{~h}$ (a), 72 h (b), 96 h (c), 120 h (d), 168 h (e), and 240 h (f); (g) schematic representation of the formation process of the ZSM-5 plates. 
The structure evolution was further monitored after the full crystallization of ZSM-5 plates at $120 \mathrm{~h}$. A minor diffraction peak, possibly ascribe to MOR, appeared at $168 \mathrm{~h}$ and remarkably intensified at $240 \mathrm{~h}$. Meanwhile, the plate surface became rough and the straight edges (and angels) nearly disappeared at $168 \mathrm{~h}$. The intergrowth architecture destructed seriously and some plates were broken at $240 \mathrm{~h}$, together with a small amount of thin plates. All these observations suggested the intergrowth ZSM-5 plates, formed after the full crystallization at $120 \mathrm{~h}$, were etched as extending the time of hydrothermal treatment. The plates were dissolved into the synthetic solution and re-nucleated into new crystals, resembling the Oswald Ripening mechanism. The dissolution initiated at the surface of the plates, unlike the ripening process of MFI crystals in aqueous sodium carbonate or tetrapropyl ammonium hydroxide solutions where the dissolution started from the core of the crystal [33-35].

One important feature of an active zeolite catalyst is the presence of enough framework $\mathrm{Al}$ atoms to maintain rich density of acid sites. Despite the successful control on the thickness of MFI nanosheets, the products were usually characterized by only few amounts of $\mathrm{Al}$ incorporated into the framework, with $\mathrm{SiO}_{2} / \mathrm{Al}_{2} \mathrm{O}_{3}$ ratios above $100[12,14,15]$ or even pure silicate [16]. Higher amount of $\mathrm{Al}$ atoms incorporated into the framework of ZSM-5 nanosheets, with a $\mathrm{SiO}_{2} / \mathrm{Al}_{2} \mathrm{O}_{3}$ ratio of 40 , was achieved only with the aid of $\mathrm{F}^{-}$during the synthesis [36]. Here, the $\mathrm{SiO}_{2} / \mathrm{Al}_{2} \mathrm{O}_{3}$ ratio in the initial gel was 38.8, and that in the product was 40.1 as determined by XRF, indicating that most of the $\mathrm{Al}$ source in the initial gel was transferred to the ZSM-5 plates. Moreover, $95 \%$ of the $\mathrm{Al}$ atoms were tetrahedrally coordinated framework Al species in the HZSM-5 plates as verified by solid-state NMR (Fig. 5). The chemical shift at $54 \mathrm{ppm}$ in ${ }^{27} \mathrm{Al}$

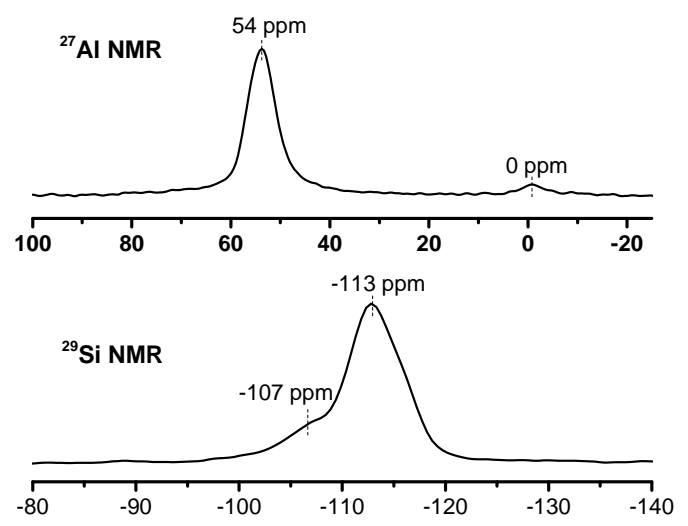

Fig. 5. Solid-state NMR spectra of the HZSM-5.

MAS NMR spectrum was ascribed to tetrahedrally coordinated framework Al species (95.4\%) [37], while the chemical shift at 0 ppm represented the extra-framework Al species (4.6\%) that might be generated during the calcination and ion-exchange processes. $\mathrm{Si}(0 \mathrm{Al})$ at $-113 \mathrm{ppm}$ and $\mathrm{Si}(1 \mathrm{Al})$ at $-107 \mathrm{ppm}$ were identified from ${ }^{29} \mathrm{Si}$ MAS NMR. Accordingly, the framework $\mathrm{SiO}_{2} / \mathrm{Al}_{2} \mathrm{O}_{3}$ ratio was estimated to be 37.5 .

Control experiments by varying the $\mathrm{SiO}_{2} / \mathrm{Al}_{2} \mathrm{O}_{3}$ ratio in the initial gel were conducted to identify the synthetic window for discriminating the crystal phase and morphology. As shown in Fig. 6, a slight increase in the $\mathrm{SiO}_{2} / \mathrm{Al}_{2} \mathrm{O}_{3}$ ratio in the initial gel from 38.8 to 50 enlarged the thickness of plates from 100-200 $\mathrm{nm}$ to about $500 \mathrm{~nm}$, although the pure ZSM-5 phase was maintained. Lowering the $\mathrm{SiO}_{2} / \mathrm{Al}_{2} \mathrm{O}_{3}$ ratio in the initial gel to 30 formed thinner plates, mostly less than $100 \mathrm{~nm}$, but ZSM-5
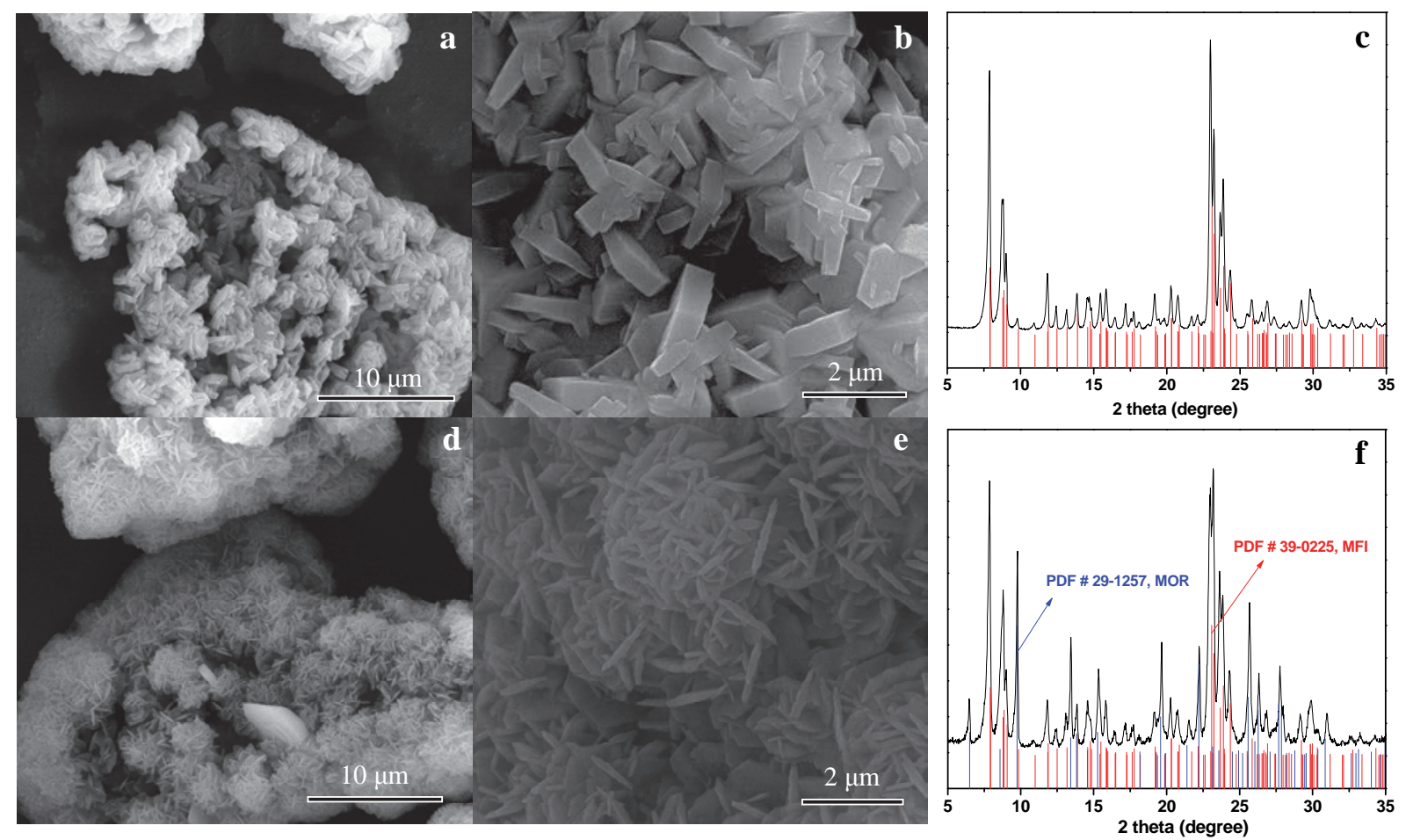

Fig. 6. SEM images and XRD patterns of the products obtained with $\mathrm{SiO}_{2} / \mathrm{Al}_{2} \mathrm{O}_{3}$ ratio of $50(a-c)$ and $30(\mathrm{~d}-\mathrm{f})$ in the initial gel. 


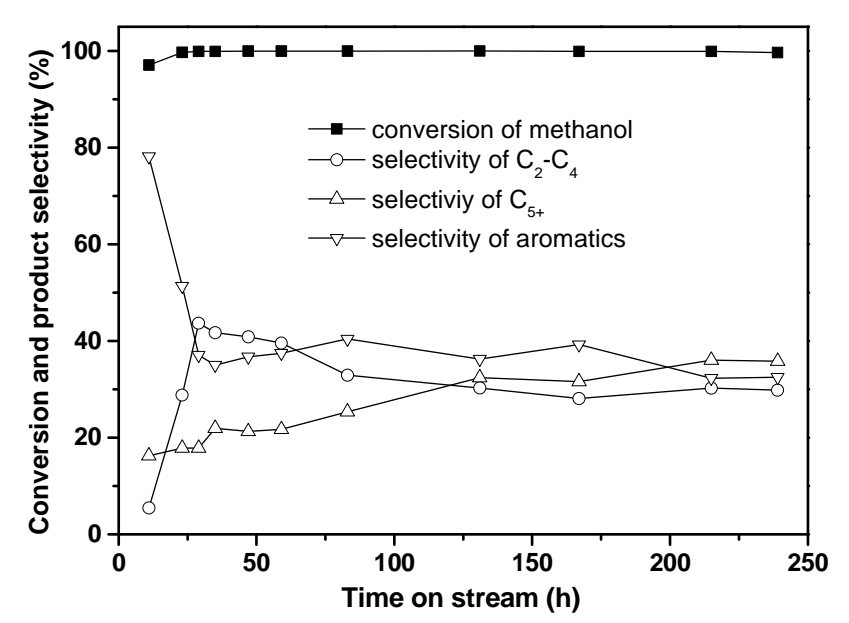

Fig. 7. Methanol to gasoline over the HZSM-5. Reaction conditions: 363 ${ }^{\circ} \mathrm{C}, 0.4 \mathrm{MPa}$, WHSV $1.0 \mathrm{~h}^{-1}$.

and MOR phases appeared simultaneously. Therefore, intergrowth ZSM-5 plates of 100-200 nm thick could be obtained only at a $\mathrm{SiO}_{2} / \mathrm{Al}_{2} \mathrm{O}_{3}$ ratio of around 40 in the initial gel under the current conditions.

HZSM-5 is typically used to catalyze the conversion of methanol to hydrocarbons and its 10 -MR pore $(0.56 \mathrm{~nm})$ allows the selective production of $\mathrm{C}_{5-11}$ hydrocarbons. However, the diffusion limitation of the traditional micro-sized HZSM-5 caused molecule trapping inside the micropores, which further reacts to form cokes that deactivate the catalyst rapidly [38]. The alleviated diffusion limit in the intergrowth HZSM-5 plates was demonstrated in the reaction of methanol to gasoline. Under the typical reaction conditions (Fig. 7), the conversion of methanol reached $\sim 100 \%$, after the induction period of $24 \mathrm{~h}$, and kept unchanged for 240 hours. The selectivity towards liquid hydrocarbons ( $\mathrm{C}_{5+}$ alkanes and aromatics) was around $70 \%$. The methanol conversion capacity, defined as the cumulative amount of methanol conversted before the conversion of methanol drops, was used as an indicator for discriminating the stability of the catalyst [39]. The methanol conversion capacity of the intergrowth HZSM-5 plates was more than 240 gmetha$\mathrm{nol} / \mathrm{g}_{\mathrm{cat}}$, which is close to the performance of the hierarchical nano-sized HZSM-5 (200-300 $\left.\mathrm{g}_{\text {methanol }} / \mathrm{g}_{\mathrm{cat}}\right)$ under simialr reaction conditions [40-43]. As compared with a conventional micro-sized coffin-like HZSM-5 with a similar $\mathrm{SiO}_{2} / \mathrm{Al}_{2} \mathrm{O}_{3}$ ratio (38), the methanol conversion capacity of the intergrowth HZSM-5 plates was 2.5 times greater than that the micro-sized HZSM-5 (Fig. 8). Apparently, the intergrowth HZSM-5 plates exhibited typical characters of hierarchical HZSM-5 with a superior stability and high selectivity towards gasoline-range hydrocarbons. This is intimately linked to the facile intra-crystal diffusion of molecules endowed by the shortened
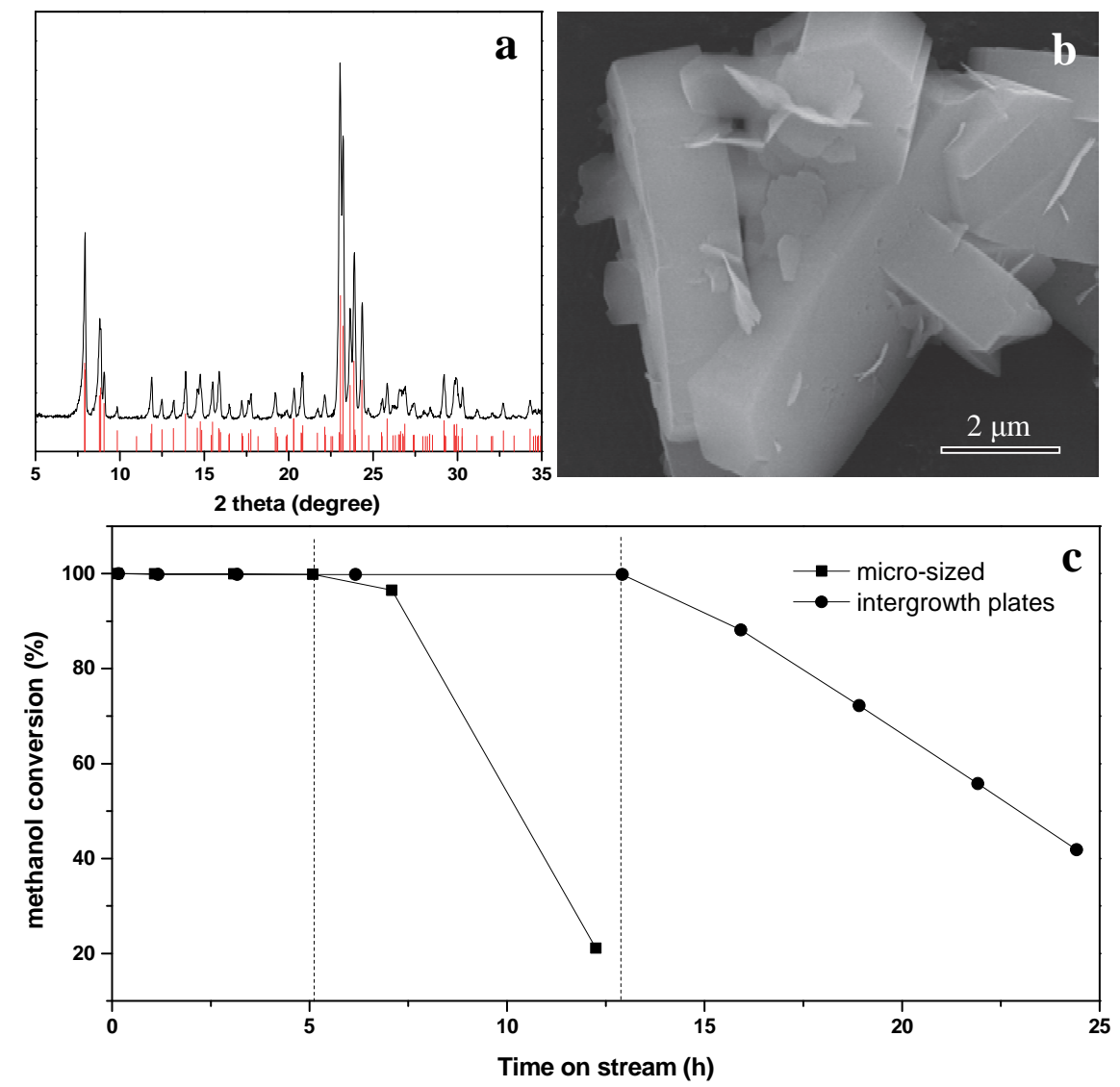

Fig. 8. XRD (a), SEM (b) of the micro-sized HZSM-5; (c) MTG performance of the micro-sized and intergrowth plates HZSM-5 catalysts. Reaction conditions: $400{ }^{\circ} \mathrm{C}, 0.1 \mathrm{MPa}, \mathrm{CH}_{3} \mathrm{OH} / \mathrm{N}_{2}=33 / 67$, WHSV $=7 \mathrm{~h}^{-1}$ (based on methanol). 
10-MR channels within the intergrowth plates.

\section{Conclusions}

Perpendicular intergrowth ZSM-5 plates were hydrothermally synthesized by using triethylene diamine as the SDA. During the crystallization process, a mother plate was initially formed on the surface of the amorphous solid gel, followed by perpendicular growth of a set of parallel plates on its surface via a homogeneous nucleation mechanism. The mother plate and the perpendicular plates had a similar thickness of 100-200 $\mathrm{nm}$ and were characterized by short straight and zigzag micropores, respectively. This unique architecture facilitated the diffusion of molecules within the zeolite catalyst and exhibited high stability in the conversion of methanol to hydrocarbons.

\section{References}

[1] G. Busca, Chem. Rev., 2007, 107, 5366-5410.

[2] J. Kärger, R. Valiullin, Chem. Soc. Rev., 2013, 42, 4172-4197.

[3] K. Li, J. Valla, J. Garcia-Martinez, Chem CatChem, 2014, 6, 46-66.

[4] S. Yang, C. Yu, L. Yu, S. Miao, M. Zou, C. Jin, D. Zhang, L. Xu, S. Huang, Angew. Chem. Int. Ed., 2017, 56, 12553-12556.

[5] S. van Donk, A. H. Janssen, J. H. Bitter, K. P. de Jong, Catal. Rev. - Sci. Eng., 2003, 45, 297-319.

[6] R. Chal, C. Gérardin, M. Bulut, S. van Donk, ChemCatChem, 2011, 3, 67-81.

[7] J. Pérez-Ramírez, C. H. Christensen, K. Egeblad, C. H. Christensen, J. C. Groen, Chem. Soc. Rev., 2008, 37, 2530-2542.

[8] B. Lu, Y. Yakushi, Y. Oumi, K. Itabashi, T. Sano, Microporous Mesoporous Mater., 2006, 95, 141-145.

[9] H. Zheng, F. Gao, V. Valtchev, J. Mater. Chem. A, 2016, 4, 16756-16770.

[10] S. C. Larsen, J. Phys. Chem. C, 2007, 111, 18464-18474.

[11] M. Ma, X. Huang, E. Zhan, Y. Zhou, H. Xue, W. Shen, J. Mater. Chem. A, 2017, 5, 8887-8891.

[12] M. Choi, K. Na, J. Kim, Y. Sakamoto, O. Terasaki, R. Ryoo, Nature, 2009, 461, 246-249.

[13] K. Na, M. Choi, W. Park, Y. Sakamoto, O. Terasaki, R. Ryoo, J. Am.
Chem. Soc., 2010, 132, 4169-4177.

[14] X. Zhang, D. Liu, D. Xu, S. Asahina, K. A. Cychosz, K. V. Agrawal, Y. Al Wahedi, A. Bhan, S. Al Hashimi, O. Terasaki, M. Thommes, M. Tsapatsis, Science, 2012, 336, 1684-1687.

[15] D. Xu, Y. Ma, Z. Jing, L. Han, B. Singh, J. Feng, X. Shen, F. Cao, P. Oleynikov, H. Sun, O. Terasaki, S. Che, Nat. Commun., 2014, 5, 4262.

[16] A. Chang, H.-M. Hsiao, T.-H. Chen, M.-W. Chu, C.-M. Yang, Chem. Commun., 2016, 52, 11939-11942.

[17] W. Chaikittisilp, Y. Suzuki, R. R. Mukti, T. Suzuki, K. Sugita, K. Itabashi, A. Shimojima, T. Okubo, Angew. Chem. Int. Ed., 2013, 52, 3355-3359.

[18] Q. Wu, M. Li, Y. Huang, Y. Fang, Microporous Mesoporous Mater., 2016, 226, 284-291.

[19] J. Chen, T. Liang, J. Li, S. Wang, Z. Qin, P. Wang, L. Huang, W. Fan, J. Wang, ACS Catal., 2016, 6, 2299-2313.

[20] D. G. Hay, H. Jaeger, K. G. Wilshier, Zeolites, 1990, 10, 571-576.

[21] J. H. Koegler, H. van Bekkum, J. C. Jansen, Zeolites, 1997, 19, 262-269.

[22] L. Zhang, Y. Song, G. Li, Q. Zhang, S. Zhang, J. Xu, F. Deng, Y. Gong, RSC Adv., 2015, 5, 61354-61363.

[23] G. Bonilla, I. Díaz, M. Tsapatsis, H.-K. Jeong, Y. Lee, D. G. Vlachos, Chem. Mater., 2004, 16, 5697-5705.

[24] L. D. Rollmann, J. L. Schlenker, S. L. Lawton, C. L. Kennedy, G. J. Kennedy, D. J. Doren, J. Phys. Chem. B, 1999, 103, 7175-7183.

[25] L. D. Rollmann, J. L. Schlenker, C. L. Kennedy, G. J. Kennedy, D. J. Doren, J. Phys. Chem. B, 2000, 104, 721-726.

[26] W.-H. Park, J.-H. Kim, C.-B. Chung, G. Seo, Microporous Mesoporous Mater., 2016, 227, 191-201.

[27] J. C. Jansen, Stud. Surf. Sci. Catal., 2001, 137, 175-227.

[28] C. S. Cundy, P. A. Cox, Microporous Mesoporous Mater., 2005, 82, 1-78.

[29] N. Ren, S. Bosnar, J. Bronić, M. Dutour Sikirić, T. Mišić, V. Svetličić, J.-J. Mao, T. Antonić Jelić, M. Hadžija, B. Subotić, Langmuir, 2014, 30, 8570-8579.

[30] A. I. Lupulescu, J. D. Rimer, Science, 2014, 344, 729-732.

[31] N. Ren, B. Subotić, J. Bronić, Y. Tang, M. Dutour Sikirić, T. Mišić, V. Svetličić, S. Bosnar, T. Antonić Jelić, Chem. Mater., 2012, 24, 1726-1737.

[32] V. P. Valtchev, K. N. Bozhilov, J. Am. Chem. Soc., 2005, 127, 16171-16177.

[33] C. Dai, A. Zhang, M. Liu, X. Guo, C. Song, Adv. Funct. Mater., 2015,

\section{Graphical Abstract}

Chin. J. Catal., 2020, 41: 1132-1139 doi: 10.1016/S1872-2067(20)63573-2

\section{Perpendicular intergrowth ZSM-5 plates with shortened} 10-MR pores

Ensheng Zhan, Zhiping Xiong, Yan Zhou, Mingrun Li, Pengfei Wang, Weibin Fan, Wenjie Shen *

Dalian Institute of Chemical Physics, Chinese Academy of Sciences; Institute of Coal Chemistry, Chinese Academy of Sciences;

University of Chinese Academy of Sciences

ZSM-5 plates with a perpendicular intergrowth structure was obtained by using a simple amine as the structure directing agent. The intergrowth plates of 100-200 nm thick were orientated with the (010) and (100) planes, respectively.

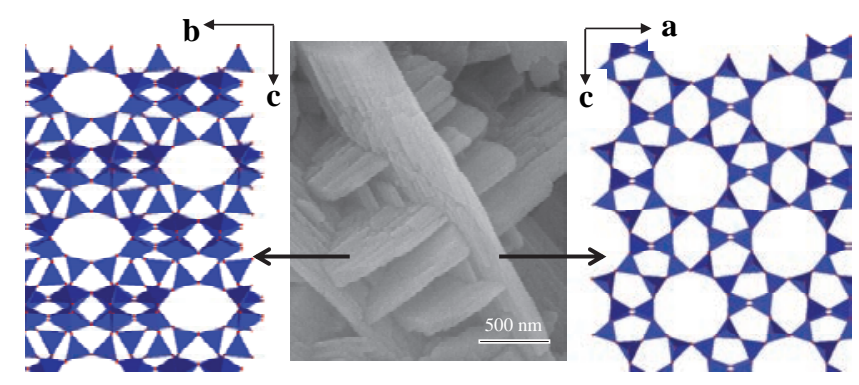


25, 7479-7487.

[34] Y. Wang, A. Tuel, Microporous Mesoporous Mater., 2008, 113, 286-295.

[35] C. Mei, Z. Liu, P. Wen, Z. Xie, W. Hua, Z. Gao, J. Mater. Chem., 2008, 18, 3496-3500.

[36] X. Zhu, L. Wu, P. C. M. M. Magusin, B. Mezari, E. J. M. Hensen, J. Catal., 2015, 327, 10-21.

[37] H. Xue, X. Huang, E. Ditzel, E. Zhan, M. Ma, W. Shen, Chin. J. Catal., 2013, 34, 1496-1503.

[38] M. Stöcker, Microporous Mesoporous Mater., 1999, 29, 3-48.
[39] M. Bjørgen, F. Joensen, M. Spangsberg Holm, U. Olsbye, K.-P. Lillerud, S. Svelle, Appl. Catal. A, 2008, 345, 43-50.

[40] A. A. Rownaghi, F. Rezaei, J. Hedlund, Microporous Mesoporous Mater., 2012, 151, 26-33.

[41] Y. Ni, A. Sun, X. Wu, G. Hai, J. Hu, T. Li, G. Li, J. Colloid Interface Sci., 2011, 361, 521-526.

[42] Z. Xue, T. Zhang, J. Ma, H. Miao, W. Fan, Y. Zhang, R. Li, Microporous Mesoporous Mater., 2012, 151, 271-276.

[43] A. A. Rownaghi, J. Hedlund, Ind. Eng. Chem. Res., 2011, 50, 11872-11878.

\title{
短10元环孔道片状垂直交错ZSM-5分子篮合成
}

\author{
展恩胜, 熊志平 ${ }^{\mathrm{a}, \mathrm{c}}$, 周 燕, 李名润, 王鹏飞 ${ }^{\mathrm{b}}$, 㚞卫斌, 申文杰, \\ a 中国科学院大连化学物理研究所, 催化基础国家重点实验室, 辽宁大连 116023 \\ b 中国科学院山西煤炭化学研究所, 煤转化国家重点实验室, 山西太原030001 \\ c中国科学院大学, 北京100049
}

摘要: 分子篮酸性位位于其亚纳米孔道中, 赋予其独特的择型催化特性, 在烃类催化转化中有重要应用. 但传统分子篮的 晶体尺寸通常在微米尺度, 因此狭长的孔道结构使得分子与活性位的接触受到扩散限制. 通过控制分子篎晶体生长习性, 选择性暴露分子篮孔道开口晶面, 截短分子篮孔道长度, 可以有效解决扩散问题. 例如通过控制ZSM-5分子篮沿b轴的生 长, 合成了具有单晶胞层厚度 $(2 \mathrm{~nm})$ 的二维片层状分子篎, 有效的促进了分子扩散、大大提高了其在甲醇转化中的寿命. 但 这类ZSM-5分子篮的合成需要使用特殊的多头季铵盐模版剂, 且一般 $\mathrm{SiO}_{2} / \mathrm{Al}_{2} \mathrm{O}_{3}$ 比大于 100 , 不利于其实际应用推广. 本文 开发了一种使用简单有机胺模版剂(TEDA)合成片状垂直交错结构ZSM-5的新方法, 并采用电子显微分析对所制ZSM-5分 子篮晶体生长方向进行了表征, 测试了其催化甲醇制汽油反应性能.

结果表明, 所得ZSM-5具有良好的结晶性和典型微孔分子篮吸附特征, 微孔表面积和微孔体积分别为 $251 \mathrm{~m}^{2} / \mathrm{g}$ 和 0.12 $\mathrm{cm}^{3} / \mathrm{g}$. 电镜结果表明, 其晶体结构特征为: 一簇平行子片垂直生长于一个母片上的交错结构, 母片呈现异于常见六边形 MFI的八边形结构, 大小约 3-5 $\mu \mathrm{m}$, 子片大小约 1-2 $\mu \mathrm{m}$, 子片和母片的厚度均约为 100-200 nm. 母片平行于MFI晶体的(010) 平面, 因此母片表面暴露直孔道开口, 且其直孔道长度约 100-200 nm. 子片与母片连接处的选区电子衍射(电子束沿[010] 方向入射)与母片的选区电子衍射完全一致, 子片垂直于[100]方向, 且子片相互间以平行方式排列, 这些证据均说明子片在 母片上的生长方式很可能是外延生长, 而非粒子堆积机理. 因此, 子片平行于MFI的(100)晶面, 表面暴露之字形孔道开口, 且之字形孔道长度约100-200 nm.

进一步通过表征不同水热晶化时间的样品, 研究了其可能的生长机制. 结果表明, 水热晶化 $72 \mathrm{~h}$ 后, XRD图出现微弱的 MFI晶体特征衍射峰, SEM显示有少量片状晶体生成, 但无交错结构; 晶化 $96 \mathrm{~h}$ 后, XRD衍射峰增强, 片状结构比例增加, 且 有交错结构出现; 晶化 $120 \mathrm{~h}$ 后, XRD呈现完美的MFI晶体衍射结构, SEM图显示均匀的交错片状结构. 72 和 $96 \mathrm{~h}$ 的样品均 为无定形物和片状(或交错片状)物共存, 说明片状(或交错片状)结构的形成不是同步进行的; 样品从开始结晶到完成结晶 所需的时间较长, 不同于分子篮结晶中常见的自催化结晶方式. 我们推测, 交错片状ZSM-5的形成发生在无定形物与溶液 相界面处, 遵循匀相成核机理.

该方法得到的ZSM-5分子篮 $\mathrm{SiO}_{2} / \mathrm{Al}_{2} \mathrm{O}_{3}$ 约为 40 , 且固体核磁表明, ZSM-5中 Al主要以骨架四配位形式存在, HZSM-5催 化剂上四配位 $\mathrm{Al}$ 的比例高达 $95 \%$ 以上, 因此其骨架有丰富的酸性位. 甲醇制汽油反应性能显示, 在 $363^{\circ} \mathrm{C}, 0.4 \mathrm{MPa}$ 条件下, 甲醇转化量 $240 \mathrm{~g}$ 时催化剂仍未失活, 表现出典型纳米ZSM-5分子篮的高稳定性特征, 这可能归结于片状ZSM-5具有短的 (100-200 nm) 直孔道或之字形孔道, 可以有效促进反应物和产物的扩散, 抑制积碳的生成.

关键词: ZSM-5; 片状结构; 垂直交错生长; 孔道长度; 多级结构; 分子扩散

收稿日期: 2019-11-11. 接受日期: 2019-12-24. 出版日期: 2020-07-05.

*通讯联系人. 电话: (0411)84379085; 传真: (0411)84694447; 电子信箱: shen98@dicp.ac.cn

基金来源：国家自然科学基金(21773229).

本文的电子版全文由Elsevier出版社在ScienceDirect上出版(http://www.sciencedirect.com/science/journal/18722067). 